慶應義塾大学学術情報リポジトリ

Keio Associated Repository of Academic resouces

\begin{tabular}{|c|c|}
\hline Title & $\begin{array}{l}\text { Bridging of macrodithionolactones to bicyclic systems. synthesis and modeling of oxapolycyclic } \\
\text { frameworks }\end{array}$ \\
\hline \multicolumn{2}{|l|}{ Sub Title } \\
\hline Author & $\begin{array}{l}\text { Nicolaou, K. C.(Abe, Yoshihiro) } \\
\text { Hwang, C. K. } \\
\text { Marron, B. E. } \\
\text { DeFrees, S. A. } \\
\text { Couladouros, E. A. } \\
\text { 阿部, 芳廣 } \\
\text { Carroll, P. J. } \\
\text { Snyder, J. P. }\end{array}$ \\
\hline Publisher & 共立薬科大学 \\
\hline Publication year & 1990 \\
\hline Jtitle & $\begin{array}{l}\text { 共立薬科大学研究年報 (The annual report of the Kyoritsu College of } \\
\text { Pharmacy). No.35 (1990. ) , p.79- } 79\end{array}$ \\
\hline \multicolumn{2}{|l|}{ JaLC DOI } \\
\hline \multicolumn{2}{|l|}{ Abstract } \\
\hline Notes & 抄録 \\
\hline Genre & Technical Report \\
\hline URL & $\begin{array}{l}\text { https://koara.lib.keio.ac.jp/xoonips/modules/xoonips/detail.php?koara_id=AN00062898-0000003 } \\
\text { 5-0079 }\end{array}$ \\
\hline
\end{tabular}

慶應義塾大学学術情報リポジトリ(KOARA)に掲載されているコンテンツの著作権は、それぞれの著作者、学会または出版社/発行者に帰属し、その権利は著作権法によって 保護されています。引用にあたっては、著作権法を遵守してご利用ください。

The copyrights of content available on the KeiO Associated Repository of Academic resources (KOARA) belong to the respective authors, academic societies, or publishers/issuers, and these rights are protected by the Japanese Copyright Act. When quoting the content, please follow the Japanese copyright act. 


\title{
Bridging of macrodithionolactones to bicyclic systems. Synthesis and modeling of oxapolycyclic frameworks.*
}

\author{
K. C. Nicolaou**, C.-K. Hwang**, B. E. Marron**, S. A. DeFrees**, \\ E. A. Couladouros**, Y. Abe, P. J. Carroll ${ }^{* *}$ and J. P. Snyder*** \\ K. C. Nicolaou**, C.-K. Hwang**, B. E. Marron**, S. A. DeFrees**, \\ E. A. Couladouros**, 阿部芳廣, P. J. Carroll ${ }^{* *}$, J. P. Snyder ${ }^{* * *}$
}

A new reaction involving bridging of macrodithionolactones to bicyclic systems is described. A series of macrodiolides was prepared and converted to the requisite macrodithionolactones. The latter substrates were induced to undergo bridging across the macrocyclic ring by exposure to sodium naphthalenide, leading to stable bicyclic systems upon addition of methyl iodide. The mixed thioketals so obtained were converted to a number of saturated or unsaturated bicyclic or polycyclic systems by removal of the sulfurs. The stereochemistry of bridging follows the relative energy of the cis and trans products rather than the conformational preferences of the macrocycles. This is confirmed by MM2 calculations and X-ray crystal structure determinations. The unusual stereochemical course of some of the reported reactions, elucidated by $\mathrm{X}$-ray, has been given a mechanistic basis by conformation searching coupled by energy evaluation by MM2 and PRDO. Several new sets of MM2 parameters were evolved during this work.

* 本報告は J. Am. Chem. Soc., 112, 3040-3054（1990）に発表.

** University of Pennsylvania

*** G. D. Searle Research and Development 